\title{
Organochlorine Pesticides in Sediment-Dwelling Animals from Mangrove Areas of the Calabar River, SE Nigeria
}

\author{
Orok E. Oyo-Ita ${ }^{1}$, Bassey O. Ekpo ${ }^{1}$, Peter A. Adie ${ }^{2} \&$ John O. Offem ${ }^{1}$ \\ ${ }^{1}$ Environmental \& Petroleum geochemistry Research Group (EPGRG), Department of Pure and Applied \\ Chemistry, University of Calabar, Nigeria \\ ${ }^{2}$ Department of Chemistry, Benue State University, Makurdi, Nigeria \\ Correspondence: Orok E. Oyo-Ita, Environmental \& Petroleum geochemistry Research Group (EPGRG), \\ Department of Pure and Applied Chemistry, University of Calabar, Nigeria. Tel: 234-706-948-3226. E- mail: \\ orokoyoita@yahoo.com
}

Received: February 7, 2014 Accepted: February 26, 2014 Online Published: June 28, 2014

doi:10.5539/ep.v3n3p56 URL: http://dx.doi.org/10.5539/ep.v3n3p56

\begin{abstract}
Sediment-dwelling biota such as mollusks (clam) and crabs collected from mangrove areas of the Calabar River are important routes of exposure to organochlorine pesticides (OCPs) contamination. Residual levels of OCPs including HCHs, DDTs, heptachlor, heptachlor epoxide, aldrin, endrin ketone, entrin aldehyde, dieldrin, endosulfan, endosulfan sulphate, methoxychlor, were determined in these organisms. The results revealed the OCP loads to be predominated by DDTs and HCHs (much of which was derived from illegal usage of GAMMALIN 20 for fishing) with the overall means of 49.6 and $35.1 \mathrm{ng} / \mathrm{g}$ wet weight (ww), respectively, at $100 \%$ frequencies of occurrence. Concentrations of other OCP components were generally low and were not detected in all biota samples. This probably reflects low utilization of these OCPs in the region and/or low bioaccumulation potential in the biota species. In general, the OCP concentrations were higher in freshwater mollusks and crabs than in brackish water, indicating that freshwater biota were more easily influenced by OCPs than their brackish water counterparts. One way analysis of variance (ANOVA) indicated no significant relationship between lipid content (LC) or body size of organisms and contaminant load, probably because of the non-equilibrium situation: smaller animals accumulated more OCPs than their larger counterparts, suggesting different uptake and elimination rates for these compounds. Biota-sediment accumulation factors (BSAFs) for DDTs and HCHs varied among the organisms and were in the ranges $1.02-9.78$ and $0.74-8.72$, respectively, indicating probably that HCHs were less bio-available in the river than DDTs. They were generally lower for highly polluted site (UMA; freshwater area) and higher for areas of low anthropogenic pressure (MR- brackish water area). Risk assessment matched against various standards clearly showed that the biota were highly contaminated with HCHs and DDTs, and may pose serious health threats to local inhabitants of the catchments. Furthermore, other selected OCPs such as heptachlor and dieldrin may in addition pose life-time cancer risk, especially to residents of the riverine/coastal communities who often consume more of these organisms than those living inland.
\end{abstract}

Keywords: mangrove sediment, biota, GAMMALIN 20, fate and risk assessment

\section{Introduction}

Organochlorine pesticides (OCPs) including hexachlorocyclohexanes (HCHs: $\alpha-\mathrm{HCH}$ - which account for about $60 \%$ of technical mixture; $\beta-\mathrm{HCH}$ - having the highest toxicity and accumulation potential for aquatic organisms; $\gamma-\mathrm{HCH}$ - constituting about $100 \%$ lindane which is a major component of GAMALIN-20; and $\delta$-HCH comprising about $20 \%$ of the technical mixture), together with dichlorodiphenyltrichloroethane (DDT) and its metabolites, dichlorodiphenyldichloroethane (DDD) and dichlorodiphenyldichloroethylene (DDE) are not only ubiquitous in the environment, but are also capable of posing serious health threat to resident macro-fauna and humans through bioaccumulation and bio-magnification via food chain (Yang, Lui, Su, Ou, Liu, Cheng, \& Hofmanni, 2006; Guo, Zeng, Wu, Meng, Mai, \& Luo, 2007; Guan., Wang, Ni, \& Zeng, 2009; Liu., Zhang, Tao, $\& \mathrm{He}, 2010)$. This is due to their resistance to environmental alteration and potential toxicity. Thus, their use has been banned in many countries of the world as they are considered priority pollutants and included in the 2001 Stockholm Convention of the United Nation (Grimalt. van-Drooge, Ribes, Vilanova., Fernandez, \& Appleby, 
2004) to which Nigeria was a signatory. Despite this global ban, these chemicals are still commonly used in developing countries such as Nigeria. Therefore, contrary to the developed countries scenario, the body tissue loads in contemporary population in developing countries are expected to be high.

In Nigeria for the past few decades, a very good percentage of imported OCP products were applied for malaria vector control. A minor proportion was used for agriculture. This is due to the dearth of large-scale commercial farming and the prevalence of subsistence farming. The circumstances have today changed and a reverse trend is gradually emerging as the Cross River State government recently embarked on large-scale cultivation of pineapple, cocoa and other fruits within Akamkpa locality (upper Cross River state) for subsequent processing and export. This has triggered large scale importation and application of new sources of DDTs as well as mosquito treated nets in the region.

An important route of exposure to OCPs from various sources is via food consumption. Different studies have shown that exposure to OCPs has become a serious public health concern (Liu et al., 2010). For example, many authors (eg. Yang et al., 2006; Guo et al., 2007; Maclntosh, Spengler, Ozkaynak, Tsai, \& Ryan, 1996) have observed that certain proportion of the adult population may be exposed to OCPs in seafood products at levels above the permissible levels by Council of the National Academy of Sciences (NAS). Environmental Working Groups have also found that children exposure to OCPs may cause immediate adverse outcomes (Wiles, Davies \& Campbell, 1998).

Risk assessments of human health have been undertaken worldwide by many researchers to examine the potential risk associated with exposure to toxic compounds in different environmental compartments and seafood products including crab and mollusk (e.g. Yang et al., 2006; de Souza, Machado Torres, Meire, Neves, Couri, \& Serejo, 2008). The importance of this biota to human health globally makes it imperative that information concerning the state of OCPs contamination in the biota be urgently obtained for the region. The information is needed to highlight the impact of OCPs on consumers, particularly on the inhabitants of the riverine/coastal communities commonly observed to consume more of this biota than their counterparts living hinterland. The health consequences associated with historical usage and application of new sources of DDTs and HCHs to the environment via aquatic organisms consumption have spurred many researchers worldwide to undertake quality assessment of this biota. The present study is the first quality assessment undertaken on crabs and mollusks from the Calabar River.

From the global standpoint, OCPs levels are relatively well established but on a local scene, there is still little or no data for many sites, particularly in the case for Sub-Saharan tropical African mangrove region. As part of the coastal environment, mangroves may be exposed to organic contamination from various sources including industrial wastes and agricultural runoff, etc. Because of its distinctive characteristics, mangrove ecosystem appears to be a favorable environment where uptake, accumulation and conservation of organic contaminant can take place (Ke, Wong, \& Tam, 2005). It is also a nursery, development and feed area for many aquatic organisms (Mille, Guiliano, Asia, Malleret, \& Jalaluddin, 2006; de Souza et al., 2008). To the best of our knowledge, little or no data concerning levels of OCPs in crab and mollusk from Sub-Saharan African mangrove areas are available. The present study will therefore contribute to the extension of data available for mangrove zones worldwide.

According to Yang et al., (2006), the controlling factors that determine the accumulation of organic contaminants in aquatic biota include sex, age, body size, lipid content and health status of organism. In addition to these physiological factors, nature of chemical compounds and their bioavailability have also been demonstrated to play a major role in bioaccumulation (Muncaster, Omokaro, Holzolehner, \& Udensi, 1990). Due to the observed relationship between bioaccumulation and biological abnormalities in aquatic biota (Yang et al., 2006; de Souza et al., 2008), it is necessary that information on the bioavailability of OCPs be obtained for the region. Aquatic biota, on exposure to sediment impacted by organic contaminants, indiscriminately ingests this sediment while foraging, and may transfer these contaminants to higher trophic levels through the food chain.

Mollusks and crabs have been demonstrated as bio-indicators of the extent of contamination of many river systems (Zuloaga, Prieto, Usobiaga, Sarkar, Chatterice, Bhattacharya, Adam, \& Satpathy, 2009; Liu et al., 2010). The species of these biota investigated in the present study are abundant groups of sediment-dwelling macro-zoobenthos within the region as exemplified by their high consumption rate. They are also readily distinguishable from other species and constitute a major ingredient in almost every meal prepared in Nigeria. Many researchers have demonstrated the usefulness of different species of crabs (e.g. Scylla serratab and Ovalipes punctatusb) and mollusks (e.g. Solen grandis and Scapharca subcrenata) as bio-indicators of organic and metallic pollution in estuaries and rivers (Guo et al., 2007; de Souza et al., 2010). However, this study 
reports for the first time in the study area the use of the species, Musculin securis and Egeria radiate (mollusk-clam) as well as Callinectes amicola and Micropipus depurator(crabs) as bio-indicators of OCPs contamination.

The main objectives of the present study were to: (1) determine the extent of OCPs contamination, (2) determine factors that influence the accumulation of OCPs in sediment-dwelling animals, (3) determine biota-sediment accumulation factors (BSAFs) in order to assess the bio-availabilities of these compounds in the river and (4) carry out risk assessment related to the consumption of the biota in order to identify potential health risks.

\section{Samples and Methods}

\subsection{Study Area and Samples}

Detail about the study area is as described by CRBDA (1982), Asuquo (1989), Löwenberg \& Künzel (1992), Ekpo \& Ibok (1998), Oyo-Ita, Offem, Ekpo \& Adie (2013). Briefly, the lower reaches of the Imo River (where biota and associated sediment samples was collected-MR site; Figure (1) are influenced by semi-diurnal ocean tides. The inhabitants of the riverine/coastal communities of the area engage in fishing activities mostly to meet domestic/local needs (a good number of them are involved in illegal use of GAMMALIN 20 - a chemical substance known to contain high levels of lindane - to catch/kill fish). On the other hand, some of them, particularly dwellers of the upper Cross River region (close to where biota and associated sediment samples were collected-UMA site; Figure(1) are subsistent farmers, cultivating vegetables, pineapple, banana, plantain, cocoa, etc. Widespread application of pesticides in agriculture was not a common practice by these peasant farmers, until the advent of large-scale commercial agriculture recently introduced by the Cross River State government involving utilization of old and new DDT sources. As a result, runoff of agricultural waste could significantly contribute to the pollutants load in the river, especially near area where both biota and associated sediment samples were collected-UMA).

The current relatively high cost of biota may be associated with their gradual extinction occasioned by enhanced anthropogenic activity.

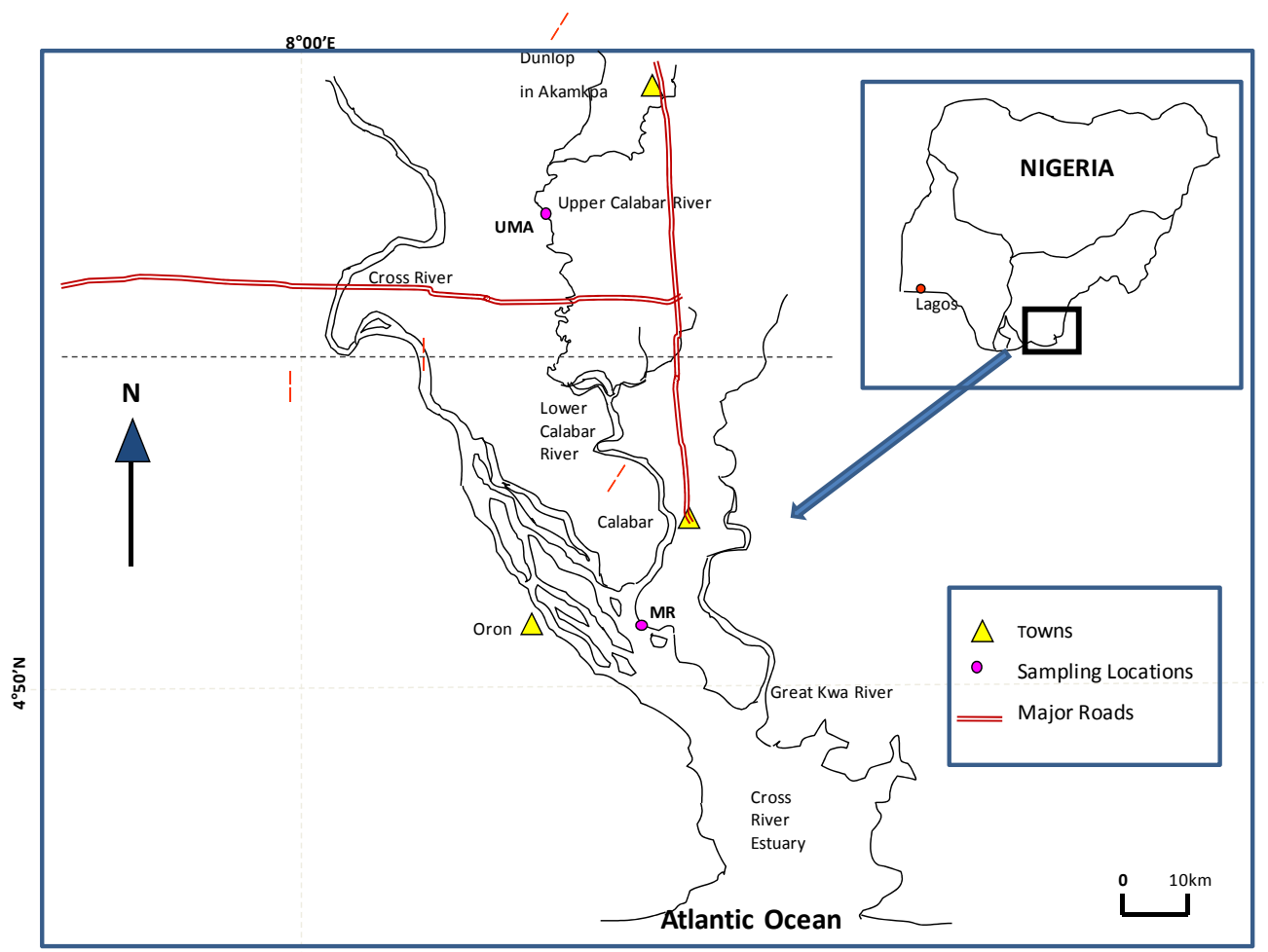

Figure 1. Map of the study area indicating sample locations 
Information on current fishery products (including crabs and mollusks) caught from Calabar River is not available. However, in 2008, the USAID/West Africa reported the total 579,537 metric tons of fishery products caught for Nigeria as highest in West Africa (USAID, 2008). In order to reduce over-dependence on imported seafood products, the Nigerian government recently embarked on extensive commercial fishery for both domestic consumption and export.

Sediment-dwelling animal samples (crabs and mollusks-clam) were captured on April, 2011 towards the mouth of the river (MR; brackish water) and upper river mangrove area (UMA; fresh water) using a woody pike and/or by hand, with the associated sediments simultaneously (using stainless steel trowel) (Figure 1; Yang et al., 2006). These two sites were chosen on the basis of assumed differential in the degree of OCPs contamination. For instance, higher influx of OCPs from agricultural run-off is expected to occur at UMA relative to MR site. Each biota contained at least 20 individuals of different sizes. Two sizes (small $\leq 2$ and large $\geq 2$; determined by measuring the weight and length of the animals) were chosen. At the UMA site (characterized by input from agricultural waste, commercial fishery activity and garbage discharge), crab and mollusk species collected were Micropipus depurator and Musculin secures, respectively, whereas the species Egeria Radiate (Mollusk-clam) and Collinectes amicola (crabs) were collected at the MR site (characterized by offshore oil spill influx, commercial fishery activity and vehicle emission) for analysis. The biota samples were separated according to their type and left overnight in filtered seawater. This allowed them to empty their guts without losing hydrophobic contaminants. The following morning, the animals were removed, freeze-dried and stored at $-20^{\circ} \mathrm{C}$ before further processing.

\subsection{Materials and Quality Assurance}

Pesticides mixture standards, and $o, p^{\prime}$-DDD, $o, p^{\prime}$-DDE as well as $o, p^{\prime}$-DDT (Acustandards) purchased from Supelco, Bellefont, PA, USA were used for identification and quantification. Surrogate standard, 2,4,5,6-tetrachloro- $m$-xylene obtained from Ultra Scientific (New Kingstown, RI, USA. SX-3, Bio-Beads was used in gel permeation chromatograph. All organic solvents were re-distilled in glass assemblage before use. The following analytical grade solvents were used for the analysis: dichloromethane (DCM), methanol (MeOH), n-hexane, acetone and toluene. Silica (80-100 mesh) and alumina (100-200 mesh) were extracted with MeOH:DCM (1:1) for $72 \mathrm{~h}$ in a soxhlet system before use. Sodium sulfate was heated at $450{ }^{\circ} \mathrm{C}$ and stored in sealed containers. Distilled water was obtained with a distillation assemblage (Guo et al., 2007).

\subsection{TOC Determination, Extraction and OCPs Analysis}

Prior to lipid analysis, freeze-dried associated sediment samples were repeatedly de-carbonated in hydrochloric acid (37\%) until bubbling stopped and then rinsed continually in de-ionised water until neutral $\mathrm{pH}$. TOC determination was performed by flash combustion at $1024{ }^{\circ} \mathrm{C}$ and then followed by thermal conductivity detection in triplicate in a CHNS Elemental Analyzer, Carlo Erbar 1108.

About $5 \mathrm{~g}$ of each dried sample (biota and associated sediment) was spiked with 2,4,5,6-tetrachloro- $m$-xylene and extracted in a soxhlet assemblage for $24 \mathrm{~h}$ with $200 \mathrm{ml}$ acetone: $\mathrm{n}$-hexane $(1: 1, \mathrm{v} / \mathrm{v})$. The extract was evaporated in vauo to approximately $5 \mathrm{ml}$ at $30{ }^{\circ} \mathrm{C}$. An aliquot (about 10\%) of the concentrate was taken out for gravimetric determination of lipid content and the remaining subjected to gel permeation chromatography using a glass column packed with $40 \mathrm{~g} \mathrm{SX}-3$ Bio-Beads. The well-packed column, loaded with an extract was eluted with $50 \%$ dichloromethane in $\mathrm{n}$-hexane for lipid removal. The fraction containing OCPs was collected and concentrated. Subsequent cleanup was performed with a multi-layer alumina/silica column packed, from bottom to top, with a neutral alumina $(6 \mathrm{~cm}, 3 \%$ deactivated) and silica gel $(12 \mathrm{~cm}, 3 \%$ deactivated), and anhydrous sodium sulfate $(1 \mathrm{~cm})$. The defatted sample was eluted with $70 \mathrm{ml}$-hexane: dichloromethane $(7: 3 \mathrm{v} / \mathrm{v})$. The eluent OCPs were concentrated and quantitatively transferred into a $2 \mathrm{ml}$ vial. This was further concentrated to a final volume of $100 \mu \mathrm{l}$ under a gentle nitrogen stream. An internal standard was added to the fraction prior to instrumental analysis.

\subsection{Instrumental Analysis}

Instrumental analysis was carried out with a Hewlett-Packard (HP, Avondale, PA, USA) 5890 gas chromatograph and 5973 mass spectrometer operated in the selective ion monitoring mode. A $30 \mathrm{~m} \times 0.25 \mathrm{~mm}$ (id) $\mathrm{x} 0.25 \mu \mathrm{m}$ (film thickness) DB-5 fused silica capillary column was used for chromatographic separation. The column temperature was programmed from $80{ }^{\circ} \mathrm{C}$ (held for $1 \mathrm{~min}$. to $200{ }^{\circ} \mathrm{C}$ at the rate of $12{ }^{\circ} \mathrm{C} / \mathrm{min}$, followed by an increase at a rate of $10 / \mathrm{min}$ to $220^{\circ} \mathrm{C}$, and the temperature was further ramped at a rate of $15^{\circ} \mathrm{C} / \mathrm{min}$ to $290{ }^{\circ} \mathrm{C}$ (held for $10 \mathrm{~min}$ ). Ultrahigh purity helium (99.99\%) was employed as carrier gas at a constant pressure of $10 \mathrm{psi}$. Splitless injection of $1 \mu \mathrm{l}$ sample was performed with a 10 min solvent delay time. Injector and detector temperatures were set at $280^{\circ} \mathrm{C}$ and $300{ }^{\circ} \mathrm{C}$, respectively. 
Mass spectra were acquired in the electron impact mode with an impact voltage of $70 \mathrm{eV}$. Data acquisition and processing were performed with a DOS based HP ChemStation System. The 21 OCPs in the samples were identified on the basis of their retention times and ion fragment profile compared against authentic standards, while quantification was done using multi-point internal calibration method. The correlation coefficient $(\mathrm{r})$ for all calibration curves were greater than 90.969 . The limits of detection of the 21 OCPs were defined as signal-noise ratio $>3$, ranging from 0.01 to $0.05 \mathrm{ng} / \mathrm{g}$. For each batch of 5-12 samples, a procedural blank, a spiked blank, a pair of spiked matrix sample/duplicate, and a sample replicate were processed. The mean recovery of the surrogates added to each sample was $59.8 \pm 12.5 \%$. Recoveries of 21 OCPs in six spiked blanks ranged from $68.2 \pm 17.2 \%$ for aldrin to $102.7 \pm 17.4 \%$ for methoxychlor. No target compounds were found in the procedural blanks, and the final concentrations were not corrected with surrogate recoveries.

\subsection{Biota Sediment Accumulation Factor (BSAF) and Health Risk Assessment Index}

In the present study, biota sediment accumulation factors were calculated according to the accompanying equation:

$$
\mathrm{BSAF}=\frac{\mathrm{C}_{\mathrm{b}} / \mathrm{f}_{1}}{\mathrm{C}_{\mathrm{s}} / \mathrm{f}_{\mathrm{oc}}}
$$

Where $\mathrm{C}_{\mathrm{b}}$ is the biota contaminant concentration ( $\mathrm{ng} / \mathrm{g}$ ww), $\mathrm{f}_{1}$ is biota lipid concentration (fraction by weight), $\mathrm{C}_{\mathrm{s}}$ is sediment contaminant concentration $(\mathrm{ng} / \mathrm{g} \mathrm{dw})$ and $\mathrm{f}_{\mathrm{oc}}$ is the organic carbon fraction of the sediment (fraction by weight) (Wang, Cheng, Zhang, Piao, Hu, \& Tao, 2004).

On the other hand, health risk assessment of human exposure to OCPs via crab and mollusk consumption was calculated using an index referred to as Estimated Daily Intake (EDI), according to the accompanying equation:

$$
\mathrm{EDI}=\frac{\mathrm{EDC} \mathrm{X} \mathrm{CC}}{\mathrm{BW}}
$$

(Liu et al., 2010)

Where EDC is food daily consumption, $\mathrm{CC}$ is mean contaminant concentration and BW is body weight for which $60 \mathrm{~kg}$ is typical (IPCS, 2006).

\subsection{Statistical Analysis}

Data for the OCPs were examined statistically in order to determine any significant environmental variation. All statistical analyses were performed using the statistical package, STATISTICA 8.0. These include descriptive statistic (e.g. a measure of dispersion) and analysis of variance. The objectives of the statistical analyses were to define the environmental characteristics of the sediments in relation to the biota, examine the relationship between samples, and assess the extent of the occurrence of OCPs.

Analysis of variance (ANOVA) is a statistical techniques used to investigate the different sources of variability associated with a series of results. It enables the effects of each source to be assessed separately and compares with other(s) using F-test.

To estimate the extent of crab and mollusk consumption in the region, 250 questionnaires were sent to families living in Calabar city and its environs as well as to inhabitants of the riverine/coastal communities. Information on the number of people (including children), consumption frequencies and quantities of crabs and mollusks consumed were included in the questionnaires. The overall consumption information for the region was obtained after statistical analysis of generated data.

\section{Results and Discussion}

The results presented in this study satisfied the acceptance criteria suggested by Burns, Mankiewiez, Bence, Page, \& Parker (1997), implying the analytical procedures met the required quality control standard. Characteristic features of the environment, biota sample type and size, and gravimetric data including extractable organic matter (EOM) and lipid content (LC) are presented in Table 1. The mean LC for the mollusks and crabs were in the range $1.72 \pm 0.24-1.78 \pm 0.16 \%$ and $1.62 \pm 0.41-1.78 \pm 0.17 \%$, respectively at the MR site, whereas at the UMA site, $1.44 \pm 0.32-1.56 \pm 0.21 \%$ and $1.92 \pm 0.42-2.02 \pm 0.67 \%$ ranges were respectively recorded for mollusks and crabs. The following OCP compounds were detected in the biota and associated sediment samples: $\alpha-\mathrm{HCH}, \beta-\mathrm{HCH}, \gamma-\mathrm{HCH}, \delta-\mathrm{HCH}$, heptachlor, heptachlor epoxide, aldrin, endosulfan, endosulfan sulphate, $o, p$-DDE, $p, p$-DDE, $o, p$-DDD, $p, p$-DDD, $o, p$-DDT, $p, p$-DDT, dieldrin, endrin, endrin ketone, endrin aldehyde, and methoxychlor. 


\subsection{OCP Concentrations in Biota and Associated Sediments}

The mean concentrations and ranges of OCPs in biota are listed in Table 2, while the isomeric ratios of related DDTs and HCHs as well as total $\mathrm{HCH}(\mathrm{t}-\mathrm{HCH})$ and total DDT (t-DDT) for the biota are presented in Tables 3 and 4, respectively. Generally, higher t-HCH levels were found in associated sediment samples obtained from both MR and UMA sites than t-DDT. HCH concentrations varied among the biota, and among isomers. $\alpha-\mathrm{HCH}$ mean concentrations varied from $2.3 \mathrm{ng} / \mathrm{g}$ wet weight (ww) in large size mollusk (LMK) at the MR site to a maximum of $6.4 \mathrm{ng} / \mathrm{g}$ ww in small crabs (SCRM) at the UMA site (Table 2). Generally at both sampling sites, small mollusks and crabs accumulated more $\alpha-\mathrm{HCH}$ than their larger counterparts. This pattern was also found in other $\mathrm{HCH}$ isomers as well as in the t-HCH - sum of all $\mathrm{HCH}$ isomers; Figure 2 showing that levels of HCHs in biota may be affected by body size. This observation may be due to the fact that smaller individuals have faster rates of hydrophobic contaminants uptake and slower rates of elimination than their larger counterparts (Yang et al., 2006). In general, despite the fact that $\gamma-\mathrm{HCH}$ degrades ultimately to $\alpha-\mathrm{HCH}$ in the environment (Chrysikou, Gemenetzis, Kouras, Manoli, Terzi, \& Samara, 2008), the $\gamma-\mathrm{HCH}$ isomer dominated the biota tissues compared with other isomers, indicating continued illegal usage of lindane in the form of GAMMALIN-20 for fishing in the region. Histopathological study carried out by Ezemoye \& Ogbomida, (2010) on African catfish showed effects such as distress physical activity, convulsion, eratic swimming, lose of equilibrium and increased breathing after sub-lethal administration of GAMMALIN-20. Therefore, the levels of t-HCH found in the biota are capable of posing serious health threat to the resident organisms. The next higher mean concentrations were exhibited by $\beta-\mathrm{HCH}$. These high levels of $\beta-\mathrm{HCH}$ could be explained by its relative stability to metabolic processes and resistance to microbial degradation in the environment compared with other $\mathrm{HCH}$ isomers (Guo et al., 2007; Guan et al., 2008).

Table 1. Characteristic features of the environment, body size, and lipid contents of biota

\begin{tabular}{|c|c|c|c|c|c|c|}
\hline Site feature & Species & Sample code & Weight (g) & LC (\%) & $\begin{array}{l}\text { Length } \\
(\mathrm{cm})\end{array}$ & $\begin{array}{l}\text { EOM } \\
(\mathrm{mg} / \mathrm{kg})\end{array}$ \\
\hline \multirow{4}{*}{$\begin{array}{l}\text { Mouth of river } \\
\text { (MR); offshore oil } \\
\text { spill influx, } \\
\text { Vehicle emission, } \\
\text { commercial fishery, } \\
\text { etc. }\end{array}$} & \multirow{2}{*}{$\begin{array}{l}\text { Egeria } \\
\text { radiate } \\
\text { (mollusks-cl } \\
\text { am) }\end{array}$} & SMK & $3.2 \pm 0.2$ & $1.78 \pm 0.16$ & $1.65 \pm 0.2$ & \multirow[t]{4}{*}{800} \\
\hline & & LMK & $4.4 \pm 0.21$ & $1.72 \pm 0.24$ & $\begin{array}{l}2.17 \pm \\
0.25\end{array}$ & \\
\hline & \multirow{2}{*}{$\begin{array}{l}\text { Callinectes } \\
\text { amicola } \\
\text { (crab) }\end{array}$} & SCRB & $3.1 \pm 0.42$ & $1.87 \pm 0.17$ & $\begin{array}{l}1.80 \pm \\
0.31\end{array}$ & \\
\hline & & LCRB & $12.5 \pm 0.5$ & $1.62 \pm 0.41$ & $\begin{array}{l}3.91 \pm \\
0.39\end{array}$ & \\
\hline \multirow{4}{*}{$\begin{array}{l}\text { Upper mangrove } \\
\text { area (UMA): } \\
\text { agricultural waste, } \\
\text { commercial } \\
\text { fishery,garbage } \\
\text { discharge, vehicle } \\
\text { emission }\end{array}$} & \multirow{2}{*}{$\begin{array}{l}\text { Musculin } \\
\text { securis } \\
\text { (mollusks-cl } \\
\text { am) }\end{array}$} & SMM & $3.9 \pm 0.25$ & $1.58 \pm 0.21$ & $\begin{array}{l}1.85 \pm \\
0.41\end{array}$ & \multirow[t]{4}{*}{2350} \\
\hline & & LMM & $5.2 \pm 0.22$ & $1.44 \pm 0.32$ & $\begin{array}{l}1.97 \pm \\
0.35\end{array}$ & \\
\hline & \multirow{2}{*}{$\begin{array}{l}\text { Micropipus } \\
\text { depurator } \\
\text { (crab) }\end{array}$} & SCRM & $3.1 \pm 0.44$ & $2.02 \pm 0.67$ & $2.0 \pm 0.68$ & \\
\hline & & LCRM & $14.4 \pm 0.41$ & $1.95 \pm 0.42$ & $\begin{array}{l}5.77 \pm \\
0.52\end{array}$ & \\
\hline
\end{tabular}

N/B: $\mathrm{SMK}=$ small mollusks from MR site, $\mathrm{LMK}=$ large mollusks fron MR site, $\mathrm{SCRB}=$ small crab from MR site, $\mathrm{LCRB}=$ large crab from MR site, $\mathrm{SMM}=$ small molluskr from UMA site, $\mathrm{LMM}=$ large mollusks from UMA site, $\mathrm{SCRM}=$ small crabs from OMA site, LCRM= large crab from UMA site. 
Table 2. Mean and range concentrations (ng/g ww) of OCPs in biota from the Calabar River

\begin{tabular}{|c|c|c|c|c|c|c|c|c|}
\hline Compound & SMK & LMK & SCRB & LCRB & SMM & LMM & SCRM & LCRM \\
\hline$\alpha-\mathrm{HCH}$ & $5.1(1.2-8.9)$ & $2.3(0.8-3.9)$ & $6.3(1.7-9.3)$ & $3.8(1.3-5.6)$ & $4.7(1.2-6.7)$ & $4.1(1.3-5.9)$ & $6.4(2.1-8.9)$ & $5.8(1.9-7.2)$ \\
\hline$\beta-\mathrm{HCH}$ & $11.3(3.5-14.7)$ & $6.1(1.6-9.1)$ & $9.2(3.2-13.8)$ & $7.8(2.6-11.9)$ & $12.3(4.1-15.2)$ & $8.1(2.9-12.2)$ & $9.4(3.1-13.4)$ & $7.9(2.3-10.2)$ \\
\hline$\gamma-\mathrm{HCH}$ & $13.3(5.3-17.3)$ & $10.2(4.7-15.9)$ & $21.3(10.2-31.2)$ & $11.6(6.3-17.9)$ & $31.2(19.5-41.6)$ & $12.4(3.9-16.9)$ & $13.1(3.3-17.1)$ & $9.5(3.6-12.7)$ \\
\hline$\delta-\mathrm{HCH}$ & $7.3(2.9-10.6)$ & $5.5(2.5-10.2)$ & $6.9(2.2-11.3)$ & $5.8(1.9-10.8)$ & $7.2(2.1-11.1)$ & $5,1(1.1-12.3)$ & $6.5(1.8-11.8)$ & $4,6(1.1-9.7)$ \\
\hline Heptachlor & $0.3(0.1-0.5)$ & $0.2(0.1-0.4)$ & $0.5(0.1-0.8)$ & $0.5(0.1-0.7)$ & $0.2(0.1-0.5)$ & $0.1(\mathrm{Nd}-0.3)$ & $0.1(\mathrm{Nd}-0.2)$ & $0.3(0.1-0.6)$ \\
\hline Aldrin & $0.7(0.2-1.2)$ & $0.7(0.1-0.9)$ & $1.1(0.4-2.1)$ & $0.6(1.9-8.6)$ & $0.7(0.3-1.1)$ & $0.6(0.1-0.9)$ & $0.6(0.1-0.8)$ & $0.9(0.2-1.7)$ \\
\hline $\begin{array}{l}\text { Heptachlor } \\
\text { epoxide }\end{array}$ & $0.3(0.1-0.6)$ & $0.3(0.1-0.8)$ & $0.4(0.1-0.9)$ & $0.2(\mathrm{Nd}-0.4)$ & $0.4(0.1-0.7)$ & $0.2(\mathrm{Nd}-0.5)$ & $0.2(\mathrm{Nd}-0.6)$ & $0.3(0.1-0.7)$ \\
\hline$\alpha$-Endosulfan & $2.5(0.5-6.5)$ & $2.3(0.3-6.1)$ & $0.8(0.2-2.4)$ & $3.0(0.6-5.7)$ & $3.5(0.5-6.7)$ & $2.6(1.2-6.2)$ & $2.2(0.9-5.8)$ & $3.1(1.1-7.2)$ \\
\hline$\beta$-Endosulfan & $0.1(\mathrm{Nd}-0.2)$ & $\mathrm{Nd}$ & $0.3(\mathrm{Nd}-0.5)$ & $0.1(\mathrm{Nd}-0.2)$ & $0.1(\mathrm{Nd}-0.3)$ & $0.4(0.1-0.6)$ & $0.2(\mathrm{Nd}-0.3)$ & $0.1(\mathrm{Nd}-0.2)$ \\
\hline$o, p$-DDD & $7.3(2.6-10.3)$ & $6.8(1.7-9.8)$ & $11.1(3.5-14.5)$ & $8.5(1.6-10.3)$ & $8.1(2.4-11.8)$ & $6.5(2.7-9.5)$ & $7.1(1.8-10.7)$ & $5.5(1.8-8.7)$ \\
\hline$p, p^{\prime}-\mathrm{DDD}$ & $6.1(1.9-9.8)$ & $5.4(0.9-10.1)$ & $7.1(2.2-9.8)$ & $6.8(1.6-0.8)$ & $10.1(3.2-14.7)$ & $9.5(2.4-12.8)$ & $9.1(3.1-11.5)$ & $6.8(1.9-8.9)$ \\
\hline$o, p-\mathrm{DDE}$ & $8.5(2.1-11.8)$ & $7.7(1.8-10.6)$ & $9.8(3.3-12.2)$ & $8.7(2.9-13.2)$ & $9.9(3.1-13.6)$ & $9.5(2.1-12.5)$ & $8.2(1.9-12.8)$ & $6.2(1.3-9.2)$ \\
\hline$p, p^{\prime}-\mathrm{DDE}$ & $6.5(1.7-10.3)$ & $5.8(1.2-9.6)$ & $7.2(1.8-11.1)$ & $7.0(0.9-10.6)$ & $9.5(1.9-12.7)$ & $9.0(2.3-13.0)$ & $7.5(1.3-9.9)$ & $7.1(2.0-9.8)$ \\
\hline$o, p-\mathrm{DDT}$ & $4.3(1.1-6.8)$ & $0.9(0.3-1.8)$ & $3.5(0.8-5.9)$ & $3.0(0.8-6.8)$ & $7.4(2.8-11.2)$ & $5.1(1.2-8.9)$ & $7.7(2.1-10.8)$ & $6.5(1.6-9.3)$ \\
\hline$p, p^{\prime}$-DDT & $5.5(1.8-8.7)$ & $3.8(0.8-6.8)$ & $6.7(1.4-9.3)$ & $5.1(2.0-7.8)$ & $4.8(1.1-7.1)$ & $3.3(0.8-7.9)$ & $6.5(1.5-9.1)$ & $6.1(1.8-8.8)$ \\
\hline DDT & $9.8(3.1-12) .5)$ & $4.8(1.77 .2)$ & $10.2(4.1-14.5)$ & $8.1(2.6-11.3)$ & $13.2(5.6-16.7)$ & $8.5(3.3-12.7)$ & $14.2(6.718 .2)$ & $12.5(4.815 .5)$ \\
\hline DDE & $15.0(7.8-18.7)$ & $13.5(6.8-17.6)$ & $17.0(8.2-20.7)$ & $15.7(7.6-18.4)$ & $19.4(9.8-22.3)$ & $18.5(9.5 .206)$ & $15.7(7.719 .6)$ & $13.3(6.716 .2)$ \\
\hline DDD & $13.4(6.5-17.4)$ & $12.2(5.9-16.8)$ & $18.1(8.5-21.3)$ & $5.3(6.8-17.8)$ & $8.2(3.8-14.2)$ & $16.1(7.3-19.7)$ & $16.2(8.3-19.9)$ & $13.3(6.8-16.8)$ \\
\hline Endrin & $\mathrm{Nd}$ & $\mathrm{Nd}$ & $\mathrm{Nd}$ & $\mathrm{Nd}$ & $\mathrm{Nd}$ & $\mathrm{Nd}$ & $\mathrm{Nd}$ & $\mathrm{Nd}$ \\
\hline $\begin{array}{l}\text { Endosulfan } \\
\text { sulphate }\end{array}$ & $0.8(0.3-2.3)$ & $0.3(0.1-0.7)$ & $0.9(0.4-3.1)$ & $0.5(0.2-0.9)$ & $0.4(0.1-0.8)$ & $1.2(0.6-2.2)$ & $0.7(0.3-1.3)$ & $0.4(0.1-0.8)$ \\
\hline Endrin ketone & $\mathrm{Nd}$ & $0.1(\mathrm{Nd}-0.2)$ & $0.1(\mathrm{Nd}-0.3)$ & $0.2(\mathrm{Nd}-0.3)$ & $0.1(\mathrm{Nd}-0.2)$ & $0.1(\mathrm{Nd}-0.2)$ & $0.1(\mathrm{Nd}-0.3)$ & $0.1(\mathrm{Nd}-0.2)$ \\
\hline $\begin{array}{l}\text { Endrin } \\
\text { aldehyde }\end{array}$ & $0.2(\mathrm{Nd}-0.4)$ & $0.2(\mathrm{Nd}-0.3)$ & $1.4(0.5-2.1)$ & $1.1(0.5-2.0)$ & $0.8(0.3-1.7)$ & $0.2(\mathrm{Nd}-9,5)$ & $0.3(0.1-0.7)$ & $0.3(\mathrm{Nd}-0.5)$ \\
\hline Methoxychlor & $2.8(0.8-4.4)$ & $3.5(1.5-5.9)$ & $2.5(1.1-5.2)$ & $1.6(0.8-2.6)$ & $1.2(0.5-2.5)$ & $1.9(0.9-3.1)$ & $0.9(0.3-1.8)$ & $0.5(0.2-1.1)$ \\
\hline Dieldrin & $2,8(0.8-3.1)$ & $2.2(0.6-2.9)$ & $0.9(0.2-1.5)$ & $0.5(0.1-0.9)$ & $2.1(1.5-2.9)$ & $2.1(1.3-3.1)$ & $1.7(0.9-2.5)$ & $1.3(0.5-2.1)$ \\
\hline
\end{tabular}

$\mathrm{N} / \mathrm{B}: \mathrm{Nd}=$ Not detectable; figures in parenthesis represent concentration ranges.

Table 3. Isomeric ratios of related DDTs and HCHs for the biota

\begin{tabular}{ccccc}
\hline Sample Code & DDT/(DDD+DDE) & o,p-DDT/p,p'-DDT & DDE/DDD & $\boldsymbol{\alpha}$-HCH/ $\boldsymbol{\gamma}$-HCH \\
\hline SMK & 0.3 & 0.8 & 1.1 & 0.4 \\
LMK & 0.5 & 0.2 & 1.1 & 0.2 \\
SCRB & 0.3 & 0.5 & 0.9 & 0.3 \\
LCRB & 0.3 & 0.6 & 1.0 & 0.3 \\
SMM & 0.4 & 1.5 & 1.1 & 0.2 \\
LMM & 0.2 & 1.5 & 1.2 & 0.3 \\
SCRM & 0.4 & 1.2 & 1.0 & 0.4 \\
LCRM & 0.2 & 1.1 & 1.1 & 0.6 \\
\hline
\end{tabular}


Table 4. Biota and associated sedimentary t-DDT and t-HCH concentrations, total organic carbon (TOC) contents and BSAFs

\begin{tabular}{llllllll}
\hline Site & Species & $\begin{array}{l}\text { Sample } \\
\text { code }\end{array}$ & BSAF $_{\text {DDT }}$ & $\begin{array}{l}\text { t-DDT } \\
(\mathrm{ng} / \mathrm{g})\end{array}$ & $\begin{array}{l}\text { t-HCH } \\
(\mathrm{ng} / \mathrm{g})\end{array}$ & BSAF $_{\mathrm{HCH}}$ & TOC (\%) \\
\hline $\begin{array}{l}\text { Mouth of the } \\
\text { river (MR) }\end{array}$ & $\begin{array}{l}\text { Egeria radiate } \\
\text { (mollusks-clam) }\end{array}$ & SMK & 6.47 & 35.7 & 26.8 & 5.18 & NA \\
& LMK & 7.11 & 26.8 & 33.7 & 6.32 & \\
& Callinectes amicola & SCRB & 9.78 & 44.7 & 41.2 & 8.70 & \\
(crab) & LCRB & 7.71 & 39.1 & 35.7 & 9.12 & & \\
Upper & Musculin securis & SMM & 1.49 & 46.4 & 35.2 & 1.13 & NA \\
mangrove & (mollusks-clam) & LMM & 1.65 & 45.2 & 48.8 & 1.71 & \\
& Micropipus & SCRM & 1.13 & 43.3 & 28.3 & 0.86 & \\
Associated & NA & LCRM & 1.02 & 40.6 & 34.3 & 0.74 & \\
Sediment & NA & ASM & NA & 6.5 & 102.7 & NA & 2.10 \\
\hline
\end{tabular}

N/B: NA $=$ Not applicable.

Besides the effect of body size on HCHs accumulation in sediment-dwelling organisms, the lipid content (LC) effect was also examined. LC has been shown to be an important factor that determines the accumulation of hydrophobic compounds as they are a primary site for storage of these compounds (Muncaster, Hebert, \& Lazar, 1990). According to these authors, the relative size of lipid pool affects movement of these compounds into biota tissues, implying that higher LC causes faster uptake and slower elimination of these contaminants. This gives rise to minimal accumulation of contaminants in low LC tissues compared to high accumulation in those tissues with high LCs (Hanson, Jenson, Appelquist, \& Morch 1978). However, this scenario was not observed in the present study. One-way analysis of variance (ANOVA) of HCHs concentrations in the biota at a confidence level of $95 \%$ was performed in order to test the significance of the relationship between LC or body sizes of organisms and the contaminant body burden. The calculated $\mathrm{F}$ values showed $1.63(\mathrm{df}=7 ; \mathrm{p}=0.05)$ for body size and 1.85 $(\mathrm{df}=7 ; \mathrm{p}=0.05)$ for $\mathrm{LC}$. These $\mathrm{F}$ values were less than the critical $\mathrm{F}$ value of 2.01 , implying that there were no significant relationships between these two paired variables. The implication here is that it appears there was a non-equilibrium state in which LCs in the biota tissues have not decreased or increased proportionally with contaminant load (Kelly \& Campbell, 1994; Yang et al., 2006). The mean t-HCH concentrations ranged from a minimum value of $22.1 \mathrm{ng} / \mathrm{g}$ ww in LMK at the MR site to a maximum value of $55.4 \mathrm{ng} / \mathrm{g}$ ww in SMM at the UMA site (Figure 2, 3a; mean $35.50 \pm 6.99 \mathrm{ng} / \mathrm{g} \mathrm{ww}$ ). The low standard deviation value suggests that there was no significant difference in the concentrations of t-HCH among the biota samples.

Comparing data with those for other regions, it can be seen that while the mean t-HCH levels for both mollusks and crabs in the present study were respectively about 10 and 1.7 orders of magnitude higher than those found for Yangtze estuary, China, Yang et al. (2006) and Liu et al. (2010) reported mean t-HCH concentrations for mollusks in Liaoning Province that are comparable to those found at the mouth of the river (MR site) in our study area. On the other hand, while the mean t-HCH levels recorded for crabs obtained from different rivers of southern China were about 50 times lower than those found in our study area, the levels recorded in crabs from Santos Bay, Sao Paulo, Brazil (with similar environmental characteristics) are comparable (Magalhaces, Taniguchi, Coscaes, \& Montone, 2012) to those from the study area.

On the basis of the ultimate degradation of $\gamma-\mathrm{HCH}$ to $\alpha-\mathrm{HCH}$, the ratio of the concentrations of $\alpha-\mathrm{HCH}$ to $\gamma-\mathrm{HCH}$ was therefore used to determine the age of contamination of the study sites (Guan et al., 2008). Values of the ratio $\alpha-\mathrm{HCH} / \gamma-\mathrm{HCH}$ in the present study varied from 0.02 to 0.95 (mean $=0.19$; Table 3 ), supporting recent and continued use of lindane in the region despite its deleterious effect on the environment. This result agrees with that of Chrysikou et al. (2008) who reported that values of the ratio $\alpha-\mathrm{HCH} / \gamma-\mathrm{HCH}<1$ are indicative of recent use of lindane.

The mean concentrations and ranges of DDT and its metabolites in the biota samples are summarized in Table 2 . DDE (sum of $o, p^{\prime}$-DDE and $p, p^{\prime}$-DDE) were the most abundant, followed by DDD (sum of $o, p^{\prime}-\mathrm{DDD}$ and $p, p^{\prime}$-DDD) and then DDT (sum of $o, p^{\prime}$-DDT and $p, p^{\prime}$-DDT). For the mollusks, large size individuals (LMK) 
accumulated less DDD (12.2 ng/g ww) than their small size counterparts (SMK; $13.4 \mathrm{ng} / \mathrm{g}$ ) at the MR site. Similar DDD accumulation pattern was not only observed for crab samples at the MR site where small size crabs (SCRB) accumulated (18.1 ng/g) more than their large size counterparts (LCRB; $15.3 \mathrm{ng} / \mathrm{g}$ ), but also for mollusks and crabs at the UMA site (Table 2). The mean concentrations of DDE in LMK and LCRB were lower than those in SMK and SCRB at the MR site, respectively. In the same vein, the mean DDT concentrations were lower in LMK and LCRB (4.8 and $8.1 \mathrm{ng} / \mathrm{g} \mathrm{ww}$ ) than in SMK and SCRB (9.8 and $10.1 \mathrm{ng} / \mathrm{g} \mathrm{ww}$ ) at the MR site. Similarly, the mean DDT was lower in LMM than in SMM at the UMA site.

Generally, LMK accumulated the lowest amounts of total DDT (t-DDT- sum of all DDT isomers and their metabolites) at the MR (30.9 ng/g ww), while the maximum t-DDT accumulation level was found in SCRM at the UMA site (50.8 ng/g ww; mean- 40.23 \pm 6.49 ; Figure 2, 3b). Therefore, despite the fact that both crabs and mollusks are on the same position in the food chain, crabs (irrespective of the species type and geographical location) appear to have accumulated more HCHs and DDTs than mollusks at the two sampling sites. This implies that mollusks are safer to consume than crabs. The mean t-DDT concentrations in mollusks and crabs in the present study are comparable to those found in mollusks and crabs from the Yangtze estuary, and a few southern rivers of China, somewhat suggesting similar extent of historical and new source usage of DDTs in these regions. However, while the mean t-DDT levels in mollusk samples from the Liaonimg Province of China were more than 3 times higher than those found in the present study, t-DDT levels recorded in crabs from Santos Bay, Brazil (Magalhaces et al., 2012) were about 9 times higher than those of the present study.

Although the frequency of occurrence of HCHs and DDTs in both mollusks and crabs was $100 \%$, there was no remarkable difference between levels of t-DDT and $\mathrm{t}-\mathrm{HCH}$ in both the mollusks and crabs $(\mathrm{df}=14 ; \mathrm{F}=1.97$; $\mathrm{p}=0.83 ; 95 \%$ confidence interval) and the associated sediment at the two sites (Table 4) except that these species of crabs and mollusks may have greater potential to accumulate DDTs than HCHs or that HCHs are less bio-available in the river than DDTs. Mean concentrations of HCHs and DDTs were respectively about 7 and 5 orders of magnitude higher than the sum of all other miscellaneous OCPs detected in the study area. It was also observed that the mollusk and crab samples collected from the freshwater site (UMA) exhibited higher HCHs and DDTs than those from brackish water site (MR). These results indicate that OCPs accumulation is greater in freshwater mollusks and crabs than in their counterparts in brackish water. This probably reflects the impact of contaminants from agricultural areas which is typically more prevalent in the freshwater zones. These results are consistent with that reported by Liu et al. (2010) who were of the opinion that freshwater fish and mollusk may be more easily influenced than their counterparts in marine water by OCP residues, especially in agricultural areas.

Ratios such as DDT/(DDE+DDD) and DDE/DDD have been used to indicate the extent of DDT degradation and to identify any fresh input in the environment (Lee, Lenabe, \& Koh, 2001). In the present study, the ratio $\mathrm{DDT} /(\mathrm{DDD}+\mathrm{DDE})$ among biota samples ranged from 0.2 to 0.5 with a mean of 0.3 , indicating that biodegradation of DDT to its metabolites did not only occur in the sediments prior to ingestion during foraging by the organisms, but also that historical use of DDTs in the region was more prominent in the environment than input from new DDT sources. However, our data revealed that the degree of dehydrochlorination of DDTs was higher than dechlorination, indicating the relative importance of aerobic microbes in the environment. This fact is supported by the DDE/DDD ratios which ranged between 0.9 and 1.2 with a mean of 1.1 for all the biota samples. Qiu, Zhu, Yoa, Hu, \& Hu (2005) reported that dicofol (used as pest control for cotton and fruits), characterized with high $o, p^{\prime}-\mathrm{DDT} / p, p^{\prime}$-DDT ratio, could be the new source of DDTs in southern and eastern China. In the present study, biota samples taken from the UMA site had $o, p^{\prime}$-DDT $/ p, p^{\prime}$-DDT ratios $>1$, whereas values $<1$ were found for biota samples obtained from the MR site (Table 3). These results may be a reflection of the recent application of dicofol pesticide on the large-scale pineapple farmland and other fruits, particularly in the Akamkpa area (upper Cross River State).

Endosulfans are among the few cyclodiene pesticides used extensively throughout the world as insecticides on crops. In the environment, the cyclic sulfite group of endosulfan gets oxidized to the corresponding sulfate (Endosulfan sulfate), which is more persistent than its parent compound (Kathpal, Singh, Dhankar, \& Singh, 1997; Guan et al., 2008; Liu et al., 2010). In Nigeria, endosulfan is currently being used as pest control for cotton and cocoa trees. While $\alpha$-endosulfan residues were detected in all the biota samples in relatively moderate concentrations, its isomer, $\beta$-endosulfan was found in much lower concentrations in all but one sample (Table 2). Generally, there was no regular pattern between the concentrations of endosulfan or its metabolites and body size of biota as observed for both $\mathrm{HCH}$ and DDT. Due to the dearth of reports on endosulfan in crabs or mollusks, comparison between mean concentration of $\Sigma$ endosulfan (sum of parent and metabolites) in mollusks in the present study could only be made with that of the Liaoning Province. Our data show values 2 times higher (3.1 
$\mathrm{ng} / \mathrm{g} w w)$ than that reported for the Liaoning Province $(1.5 \mathrm{ng} / \mathrm{g} w w)$, probably reflecting greater usage of endosulfan on crops in the study area.

Other OCPs in the biota samples were detected in low concentrations, reflecting their relatively low residual levels in the environment and/or relatively low potential for bioaccumulation by the species under consideration. For example, while heptachlor and its metabolites (heptachlor epoxide) were detected in all samples with mean concentrations ranging from $0.1 \mathrm{ng} / \mathrm{g}$ ww to a maximum of $0.5 \mathrm{ng} / \mathrm{g} \mathrm{ww}$, endrin was not detected in any of the biota samples (Table 2). The non-detection of heptachlor epoxide in the associated sediments and the detection of heptachlor and its epoxide metabolite in comparable amounts suggest the ease of metabolism of heptachlor to heptachlor epoxide in the biota tissues. On the other hand, the non-detection of $\beta$-endosulfan and endrin ketone in mollusks at relatively low polluted site (MR) may suggest low capacity of the mollusk species to accumulate these OCPs in relation to the crab species. Although few data are available, for example, those reported by Adie, Ekpo, Oyo-Ita, Offem (2012) on the occurrence of these OCPs in the environment, their frequencies of occurrence in biota from the study area are higher than those found in biota from other regions of the world (e.g. Guo et al., 2007; Liu et al., 2010). Generally, heptachlor represented only $1 \%$ of the total OCPs in the biota analyzed.

The mean concentrations of dieldrin in the crabs and mollusks were higher than those of aldrin, indicating that aldrin degradation did not only occur in the biota samples and/or in the environment prior to ingestion, but also suggest that dieldrin is more stable in the ecosystem than aldrin. In all samples, aldrin constituted $<1 \%$ of the total OCPs, while the percentage composition of dieldrin varied from $1 \%$ to $4 \%$. Endrin metabolites such as endrin aldehyde and ketone were also identified and quantified in almost all biota samples. Unlike in the associated sediment samples where these compounds were undetected at the two sites, most biota samples showed trace levels of the compounds (Table 2), suggesting that metabolism of endrin to its metabolites could possibly have occurred in the body tissue of the biota after initial uptake of endrin via certain pathways. The non-detection of endrin in all the biota samples reflects the effectiveness of the biota enzyme system in metabolizing this compound detected in the associated sediment samples. Endrin metabolites represented about 1 - $2 \%$ of the total OCPs measured in all biota samples. The mean concentrations of methoxychlor in both crab and mollusk samples are listed in Table 2 and constituted about $1-4 \%$ of the total OCPs measured in the biota.

\subsection{BSAFs and Health Risk Assessment}

Biota sediment accumulation factor (BSAF) is a valuable tool used in the present study for predicting bioaccumulation of OCP compounds and represents a measure of bio-availability of these compounds in the river. The total organic carbon (TOC) contents of sediments were $2.10 \%$ at the MR site and $5.21 \%$ at the UMA site (Table 4). The calculated BSAF values for DDTs were in the range 1.02-9.78, with the highest value found in small size crabs (SCRB) at the MR site, even though the associated sediment exhibited lower t-DDT concentration and TOC content (Table 4). On the other hand, the lowest BSAF value was observed in LCRM at the UMA site, with higher associated sedimentary DDT concentration and TOC content. Similarly, the BSAF values for $\mathrm{HCH}$ ranged between 0.74 and 8.70 , with the highest value observed in small size crabs (SCRB) at the MR site, even though the associated sediment exhibited lower t-HCH concentration and TOC content. On the other hand, the lowest BSAF value for HCH was found in large size crabs (LCRM) at the UMA site, with higher associated sedimentary $\mathrm{HCH}$ concentration and TOC content. These results are in agreement with those reports by Ferguson \& Chandler (1990); Lake, Rubinstein, Lee, Lake, Heltshe, \& Pavignano (1990); Yang et al. (2006) who recorded lowest BSAF values in highly polluted sediments with high TOC content and highest values in sediments with low contaminant concentrations and low TOC contents. This scenario reflects the strong affinity DDT and HCH compounds have toward sedimentary organic carbon (OC). However, the observed lower BSAF values recorded for HCHs in relation to DDTs may be a result of their stronger affinity for sedimentary OC. Thus, despite the high loads of HCHs in sediments, this contaminant may therefore be less bio-available to the resident macro-fauna.

Epidemiological survey conducted by many toxicologists (eg. Rogan \& Chen, 2005; Beard, 2006) has shown that exposure to OCPs can be associated with various adverse effects on human health and reproduction. For the past 3 decades, studies have shown that the levels of HCHs in aquatic food products have dramatically declined (Guo et al., 2007). However in the present work, HCHs have not only been detected in all biota samples but also their concentrations were relatively high. All samples had residual levels of HCHs higher than the maximum permissible value (10 ng/g) established by the European Union (Binelli \& Provini, 2003). These high levels of $\mathrm{HCHs}$ suggest that $\mathrm{HCHs}$ are still environmentally significant organic contaminants in the SE Niger Delta region of Nigeria. In addition, though $\mathrm{HCHs}$ have relatively low persistency in the environment as well as high 
biodegradability and volatility, continued usage in the region under study may be responsible for the high levels of HCHs measured in the organisms.

As mentioned earlier, the sediment-dwelling animals were also predominated by DDTs. In comparison to the maximum permissible concentration $(50 \mathrm{ng} / \mathrm{g})$ established by the European Union on the basis of lipid percentage of aquatic food products, $52.8 \%$ of our biota samples were considered overloaded with DDTs. If a relatively stricter limit for fish consumption (14.4 ng/g) recommended by the US Environmental Agency (2006) is used, the residual levels of DDTs in $85.3 \%$ of the biota samples exceeded the criterion.

Despite the low levels of other OCP residues in the biota samples, potential health risk associated with the consumption of sediment-dwelling animals in the region cannot be overlooked. The estimated daily intakes (EDIs; which is often taken as a means of assessing human exposure to organic contaminants) of selected OCP compounds ( $p, p^{\prime}$-DDT, dieldrin and heptachlor) were calculated according to Liu et al. (2010). Statistical analysis of generated data provided the overall consumption information for the region and is summarized in Table 5. The amounts ranged between 15.5 and $29.6 \mathrm{~g} /$ day, with a mean of $17.7 \mathrm{~g} /$ day for crabs, and between 10.5 and $22.4 \mathrm{~g} /$ day, with a mean value of $14.5 \mathrm{~g} /$ day for the mollusk species. The consumption data recorded in our study were lower than the average value recorded for fishery food from the China Statistical Yearbook (38.90 g/day; NBSC, 2008). On the basis of these generated data, average EDIs for selected OCPs were calculated. The overall mean concentration values for selected OCPs were used for the calculation. Potential threat to public health as a result of exposure to OCPs via biota consumption were assessed by comparison with the US Environmental Protection Agency (USEPA) benchmark concentrations estimated from the cancer slope factors that represent exposure concentrations at which life-time cancer risk is 1 in 1 million (USEPA, 2006). A benchmark concentration shows the daily concentration below which the probability of developing adverse health effect is low (Liu et al., 2010).

The p,p'-DDT and dieldrin in our samples are not only higher than the cancer benchmark concentrations, but also higher than the oral reference dose developed by USEPA, suggesting high probability of developing serious adverse effects through consumption of crabs and mollusks in the region (Dougherty et al., 2000). Besides the p,p'-DDT and dieldrin, the EDI of heptachlor also exceeded the cancer benchmark level. The implication here is that there exist the risks of developing lifetime cancer especially for inhabitants of riverine/coastal communities with potential to consume more sediment-dwelling biota than those living inland. On the other hand, the EDI of each contaminant was slightly higher in crabs than in mollusks (Table 5). This suggests that the mollusk species under study were slightly safer to consume than the species of crabs on the basis of th eir contributions to the EDIs. With limited amounts of data available on persistent organochlorine compounds in sediment-dwelling animals from coastal waters of Sub-Sahara African countries, incorporating consumption and population data from FAO fact sheet (http://post.baidu.com/f?kz=1000212531) in the present study will not only enable comparison of EDIs among the population in African region to be made but also in other regions of the world. Because of the high amounts of mollusks consumed and their high DDT concentrations measured in the present study, the EDI of DDTs via mollusks consumption in the region is higher than those recorded for other regions in the Asian pacific. The comparison may be superficial because mollusks may not entirely represent bivalves, leading to bias results. Nevertheless, the result provides a preliminary baseline for assessing the extent of human exposure to DDTs via aquatic food consumption among different countries in Sub-Sahara Africa. Furthermore, many researchers do not include children population in their health risk assessment, our study was quite encompassing as it did consider children exposure to OCPs. The inclusion of children scenario will contribute significantly to the possibility of developing cancer among the inhabitants of the region. 


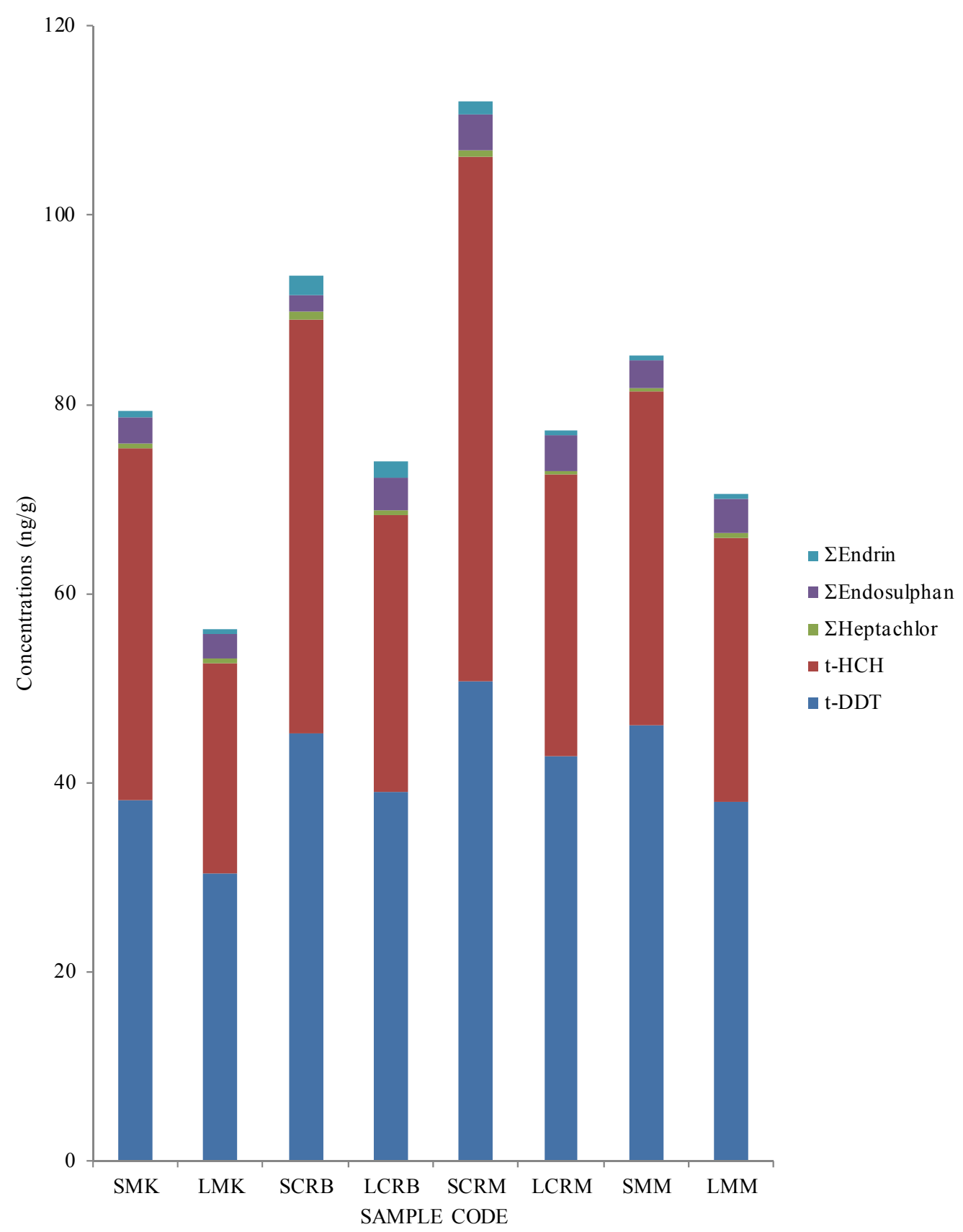

Figure 2. Distribution of OCPs in crabs and mollusks from the Calabar River 

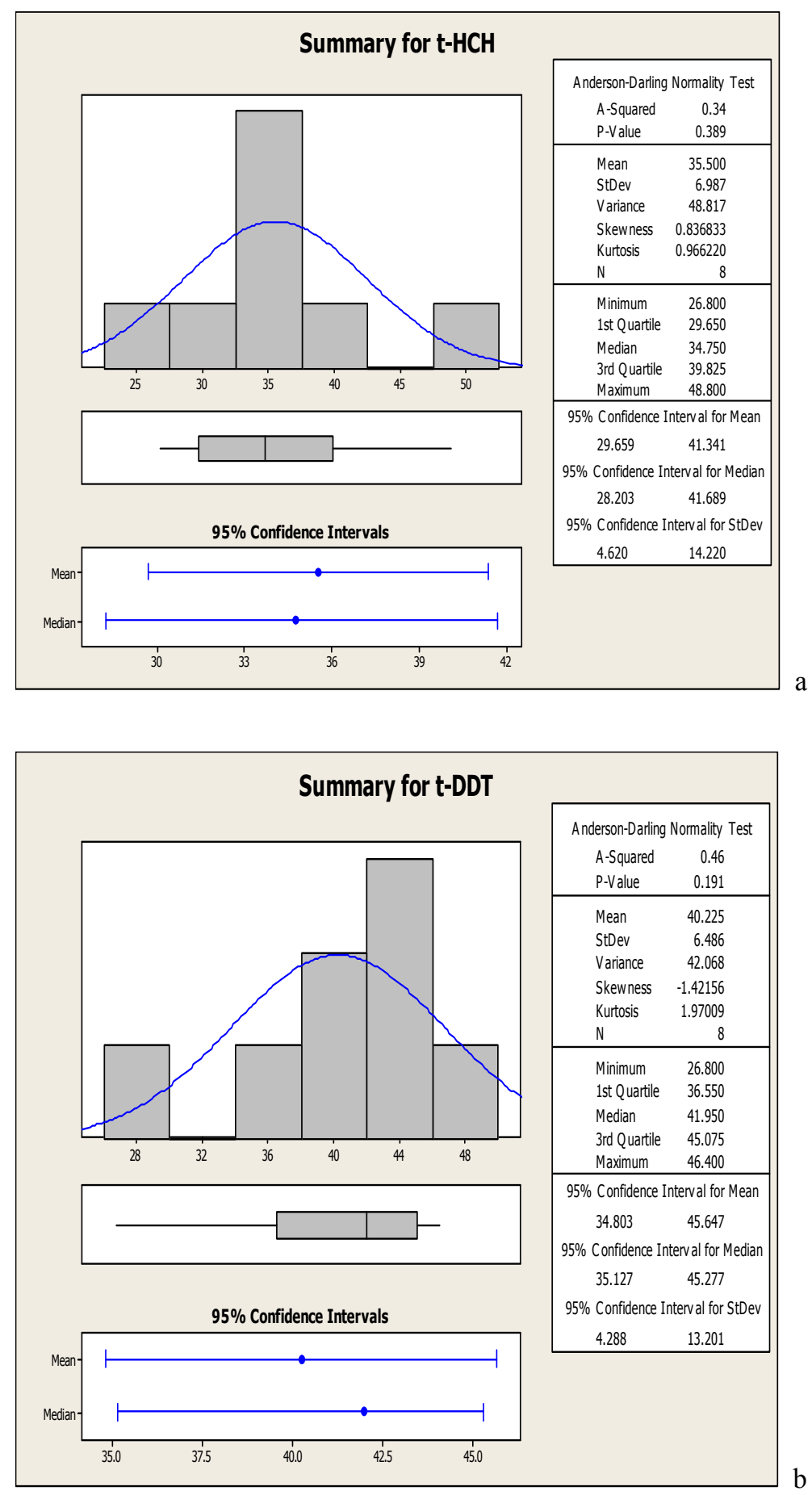

Figure 3a, b. descriptive statistics for (a) t-HCH and (b) t-DDT in biota with normal distribution curve 
Table 5. Biota consumption rate and comparison of the estimated daily intake from the present work with cancer benchmark concentration (CBC) and Oral Reference Dose (Oral RfD) developed by the US Environmental Protection Agency

\begin{tabular}{cccccl}
\hline $\begin{array}{c}\text { Contaminant } \\
\text { Name }\end{array}$ & Species & $\begin{array}{c}\text { Consumption } \\
\text { Rate (g/day) }\end{array}$ & $\begin{array}{c}\text { Average EDI } \\
(\mathrm{mg} / \mathrm{kg} . \text { day })\end{array}$ & $\begin{array}{c}\text { Oral RfD } \\
(\mathrm{mg} / \mathrm{kg} . \text { day })\end{array}$ & $\begin{array}{l}\text { CBC } \\
(\mathrm{mg} / \mathrm{kg} . \text { day })\end{array}$ \\
\hline$p, p$ '-DDT & Mollusks & 14.5 & 1.33 & 0.5 & 0.03 \\
& Crabs & 17.7 & 1.46 & --- & --- \\
Dieldrin & Mollusks & 14.5 & 0.13 & 0.5 & 0.00022 \\
& Crabs & 17.7 & 0.15 & --- & --- \\
Heptachlor & Mollusks & 14.5 & 0.42 & 0.05 & 0.0000625 \\
& Crabs & 17.7 & 0.62 & --- & --- \\
\hline
\end{tabular}

\section{Conclusions}

The present work has demonstrated the potential of organisms of lower trophic level such as crabs and mollusks to accumulate high levels of OCPs. HCHs and DDTs were the dominant OCPs measured in the biota samples collected from the Calabar River with relatively high levels of t-HCH attributable to the frequent usage of lindane in the form of GAMMALIN 20 for fishing by local fishermen. The distributions of t-HCH and t-DDT in the biota were found to be strongly dependent on geographical positions and their sources. It was also shown that there was no significant difference between lipid contents of biota and concentrations of HCH and DDT and that body size of biota affected these contaminants levels. While $\alpha-\mathrm{HCH} / \gamma-\mathrm{HCH}$ ratios showed fresh and continued inputs of $\mathrm{HCHs}$ to the river, DDT profile exhibited evidence of extensive degradation to its metabolites (DDD and DDE) with the transformation to DDE being the preferred pathway. BSAFs varied amongst biota and were generally lower in highly polluted site and higher in low impacted areas. Hence, despite the high loads of OCPs in sediments at the UMA site, these contaminants were therefore less bio-available to the sediment-dwelling organisms at this site.

EDI results for selected OCPs revealed life-time cancer risk, especially to inhabitants of the riverine/coastal areas who often consume more sediment-dwelling biota than those living inland. Therefore, for purposes of protecting public health, it is not only urgent for the appropriate government agencies to be mobilized for a remedial action but it is also needful to continually monitor the occurrence and levels of OCPs in the region. Further monitoring efforts should be aimed at identifying other species of crabs and/or mollusks with potential higher OCPs accumulation capacity.

\section{Acknowledgements}

We are thankful to the management and staff of State Key Laboratory of Organic Geochemistry, Guangzhou Institute of Geochemistry, China for accepting to run the GC-Ms analysis of our fractions at no cost and Ola Samuel of Department of Chemistry, Redeemer University of Nigeria, Ogun State for assisting in these runs during his study fellowship in the Institute.

\section{References}

Adie, P. A., Ekpo, B. O., Oyo-Ita, O. E., \& Offem, J. O. (2012). Organochkorine pesticides in coastal/mangrove sediment of the Calabar River, SE Nigeria. African Journal of Environmental Polltion \& Health, 9(2), 52-61.

Asuquo, F. E. (1989). Water quality of the Calabar River, Nigeria. Tropical Ecology, 30(1), 31-40.

Beard, J. (2006). DDT and human health. Science of the Total Environment, 355, 78-89. http://dx.doi.org/10.1016/j.scitotenv.2005.02.022

Binelli, A., \& Provini, A. (2003). POPs in edible clams from Italian and European markets and possible human health risk. Marine Pollution Bulletin, 46, 879-886. http://dx.doi.org/10.1016/S0025-326X(03)00043-2

Burns, W. A., Mankiewiez, P. J., Bence, A. F., Page, D. S., \& Parker, K. R. (1997). A principal-component and least-square method for allocating Polycyclic aromatic hydrocarbons in sediment to multiple sources. Environmental Toxicology \& Chemistry, 1119-1131. http://dx.doi.org/10.1002/etc.5620160605

Chrysikou, L., Gemenetzis, P., Kouras, A., Manoli, E., Terzi, E. \& Samara, C. (2008). Distribution of persistent organic pollutants, polycyclic Aromatic hydrocarbons and trace elements in soil and vegetation following a 
large scale landfill fire in northern Greece. Environment International, 34, 210-225. http://dx.doi.org/10.1016/j.envint.2007.08.007

Cross River Basin Development Authority (CRDA). (1982). Inventory of Natural sites conditions- soils, slopes, hydrology, land use and vegetation throughout the area of operation of the Authority. Progress report, 4, $1-45$.

De Souza., A. S., Machado Torres, J. P., Meire, R. O., Neves, R. C., Couri, M. S., \& Serejo, C. S. (2008). Organochlorine pesticides (OCPs) and polychlorinated biphenyls (PCBs) in sediments and crabs (Chasmagnathus granulate, DANA, 1851) from mangroves Guanabara Bay, Rio De Janeiro State, Brazil. Chemosphere, 73, 186-192. http://dx.doi.org/10.1016/j.chemosphere.2007.04.093

Dougherty, C. P., Holiz, S. H., Reinert, C., Panyacosit. L., Axrlrad, D. A., \& Woodruff, T. J. (2000). Dietary exposures to food contaminants across United States. Environmental Research, 84, 170-185. http://dx.doi.org/10.1006/enrs.2000.4027

Ezemonye, L., \& Ogbimida, E. (2010). Histopathological effect of GAMALIN 20 on African catfish. Applied \& Environmental Soil Science, 8-13.

Ferguson, P. L., \& Chandler, G. T. (1998). A laboratory and field comparison of sediment polycyclic aromatic hydrocarbons bioaccumulation by the cosmopolitan estuarine polycheate stieblospio benedicti (Webster). Marine Environmental Research, 45, 387-401. http://dx.doi.org/10.1016/S0141-1136(98)00101-9

Grimalt, J. O., van Drooge, B. L., Ribes, A., Vilanova, R. M., Fernandez, P., \& Appleby, P. (2004). Persistent organochlorine compounds in soils and sediments of European high altitude mountain lakes. Chemosphere, 54, 1549-1561. http://dx.doi.org/10.1016/j.chemosphere.2003.09.047

Guan, Y., Wang, J., Ni, H., \& Zeng, E. Y. (2009). Organochlorine pesticides and polychlorinated biphenyls in riverine runoff of the Pearl River Delta, China: Assessment of mass loading input source and nvironmental fate. Environmental Pollution, 157, 618-624. http://dx.doi.org/10.1016/j.envpol.2008.08.011

Guo, J-Y., Zeng, E. Y., Wu, F.G., Meng, X. Z., Mai, B. X., \& Luo, X-J. (2007). Organochlorine pesticides in seafood products from Southern China and health risk assessment. Environmental Toxicology \& Chemistry, 26(6), 1109-1115. http://dx.doi.org/10.1897/06-446R.1

Hanson, N., Jenson, Y. B., Appelquist, H., \& Morch, E. (1978). The uptake and release of petroleum hydrocarbons by the marine mussels Mytilus edulis. Prog. Water Technology, 10, 351-359.

International Programme on Chemical Safety (IPCS). (2006). Inventory of IPCS and other WHO pesticide evaluations and summary of toxicological evaluations performed by the joint meeting on pesticide residues (JMPR) through 2005. Retrieved December, 2012, from http://www.who.int/ipcs/publications/jmpr/jmpr_pesticide/en/index.ht ml

Kathpal, T. S., Singh, A., Dhankar, J. S., \& Singh, G. (1997). Fate of endosulfan in cotton oil under sub-tropical $\begin{array}{llllll}\text { conditions of northern India. Pesticide } & \text { Science, } & \text { 50, }\end{array}$ http://dx.doi.org/10.1002/(SICI)1096-9063(199705)50:1<21::AID-PS550>3.0.CO;2-N

Ke, L., Yu, K. S. H., Wong, Y. S., \& Tam, N. F. Y. (2005). Spatial and vertical distribution of polyaromatic hydrocarbons in mangrove sediments. Science of the Total Environment, 340, 177-187. http://dx.doi.org/10.1016/j.scitotenv.2004.08.015

Kelly, A. G., \& Campbell, L. A. (1994). Organochlorine contaminants in liver cod (Gadus morhua) and mussles of herring (Clupea harengus) from Scottish waters. Marine Pollution Bulletin, 28, 103-108. http://dx.doi.org/10.1016/0025-326X(94)90546-0

Lake, J., Rubinstein, N., Lee, I., Lake, C., Heltshe, J., \& Pavignano, S. (1990). Equilibrium partitioning and bioaccumulation of sediment associated contaminants in faunal organisms. Environmental Toxicology \& Chemistry, 9, 1095-1106. http://dx.doi.org/10.1002/etc.5620090816

Lee, K. T., Lenabe, S., \& Koh, C. H. (2001). Distribution of organochlorine pesticides in sediments from Kyeonhhi Bay and nearby areas, Korea. Environmental Pollution, 114, 207-213. http://dx.doi.org/10.1016/S0269-7491(00)00217-7

Liu, Z., Zhang, H., Tao, M., \& He, Z. (2010). Organochlorine pesticides in consumer fish and mollusk of Liaoning province, China: distribution and human exposure implication. Arch. Environmental Contamination \& Toxicology, 59, 444-453. http://dx.doi.org/10.1007/s00244-010-9504-7 
Löwenberg, U. H., \& Künzel, T. H. (1992). Investigations on the hydrology of the lower Cross River System, Nigeria. Anim. Research \& Development, 35, 72-85.

MacIntosh, D. L., Spengler, J. D., Ozkaynak, H., Tsai, L., \& Ryan, P. B. (1996). Dietary exposures to selected metals and pesticides. Environmental Health Perspective, 104, 202-209. http://dx.doi.org/10.2307/3432790

Magalhaces, C. A., Taniguchi, S., caces, M. J., \& Montone, R. C. (2012). PCBs, PBDEs and organochlorine pesticides in crabs Hepatus Pudibundus and Callinectes danae from Santos Bay, State of Sao Paulo, Brazil. Marine Pollution Bulletin, 64(3), 662-667. http://dx.doi.org/10.1016/j.marpolbul.2011.12.020

Mille, G., Guiliano, M., Asia, L., Malleret, L., \& Jalaluddin, N. (2006). Sources of hydrocarbons in sediments of the Bay of Fort de France (Martinique). Chemosphere, 64, 1062-1073. http://dx.doi.org/10.1016/j.chemosphere.2005.12.001

Muncaster, B. W., Hebert, P. D., \& Lazar, R. (1990). Biological and physical factors affecting organic contaminants in fresh water mussels. Arch. Environmental Contaminants \& Toxicology, 9, 23-28.

National Bureau of Statistics of China (NBSC). (2008). China statistical yearbook, 2008. Retrieved February, 2012, from www.stats.gov.cn/tjjj/ndsj/2008/indexch.htm

Oyo-Ita, O. E., Offem, J. O., Ekpo, B. O., \& Adie, P. (2013). Anthropogenic PAHs in mangrove sediments of the Calabar River, SE Niger Delta, Nigeria. Applied Geochemistry, 28, 212-219. http://dx.doi.org/10.1016/j.apgeochem.2012.09.011

Qiu, X., Zhu, T., Yoa, B., Hu, J., \& Hu, S. (2005). Contribution of dicofol to current DDT pollution in China. Environmental Science \& Technology, 39, 4385-4390. http://dx.doi.org/10.1021/es050342a

Rogan, W. J., \& Chen, A. ( 2005). Health risks and benefits of bis(4-chlorophenyl)-1,1,1-Trichloroethane (DDT). Lancet, 366, 763-773. http://dx.doi.org/10.1016/S0140-6736(05)67182-6

USAID/West Africa. (2008). Trade hub annual report. Retrieved July 30, 2013, from available at http.//www.watradehub.com/resources/resourcesfiles.com

U.S. Environmental Protection Agency (USEPA). (2006). Guidance for assessing Chemical contaminant data for use in fish advisories, 2, 231-253.

Risk assessment and fish consumption limits. (2012). Retrieved February, 2012, from http://www.epa.gov/ost/fishadvice/volum2/index.html

Wang, X. J., Chen, J., Zang, Z. H., Piao, X. Y., Hu, J. D., \& Tao, S. (2004). Distribution and sources of Polycyclic Aromatic Hydrocarbons in soil Profiles of Tiajin Area, People's Republic of China. Bulletin of Environmental Toxicology, 73, 739-748.

Wiles, R., Davies, K., \& Campbell, C. (1998). Overexposed organophosphate insecticides in children's food. Washington, DC: Environmental Working Group.

Yang, Y., Lui, M., Su, L., Ou, D., Liu, H., Cheng, S., \& Hofmanni, T. (2006). HCHs and DDTs in sediment-dwelling animals in the Yangtze Estuary China. Chemosphere, 62, 381-389. http://dx.doi.org/10.1016/j.chemosphere.2005.04.102

Zulaga, O., Prieto, A., Usobiaga, A., Sarkar, S. K., Chatterice, M., Bhattacharya, B. D., Adam, M. A., \& Satpathy, K. K. (2009). Polycyclic aromatic hydrocarbons in intertidal marine bivalves of Sunderban mangrove wetland, India: an approach to bioindicator species. Water, Air \& Soil Pollution, 201, 305-331. http://dx.doi.org/10.1007/s11270-008-9946-y

\section{Copyrights}

Copyright for this article is retained by the author(s), with first publication rights granted to the journal.

This is an open-access article distributed under the terms and conditions of the Creative Commons Attribution license (http://creativecommons.org/licenses/by/3.0/). 